\title{
RECENT RECORDS \\ OF OLDSQUAW IN SOUTHEASTERN MANITOBA
}

\section{PETER TAYLOR, Box 597, Pinawa, Manitoba. R0E 1L0}

The Oldsquaw is a "sea duck" with a circumpolar distribution. It breeds in tundra regions and winters on large lakes or at sea. ${ }^{2}$ Its migration routes between the tundra and either the Pacific coast or the Great Lakes and the Atlantic both skirt the fringes of populated regions of the prairie provinces. $^{7,8}$ Therefore, occurrence in the southern prairie provinces is uncommon but not unexpected.

The frequency of sightings of several uncommon water birds in southeastern Manitoba has increased since about 1975, at least partly because of increased observer coverage of large lakes and rivers (especially Lake Winnipeg and the Winnipeg River) during migration. ${ }^{11,12,13}$ The Oldsquaw is a case in point. Sexton and Collins reviewed 20 known records of Oldsquaws in southern Manitoba between 1899 and $1976 .^{8}$ All but three of these occurred in the southeast, including six on southern Lake Manitoba and seven on or near southern Lake Winnipeg. The authors concluded that "It is plausible that a small number of Oldsquaw migrate in both spring and fall each year through southern Manitoba." ${ }^{8}$ Between 1977 and 1993, Oldsquaw records in southeastern Manitoba totalled about 90 individuals, and the species was recorded each year except 1985 and 1986. It is therefore timely to review these records, and compare the emerging pattern of occurrence with the Oldsquaw's status in neighbouring regions.
Sources of Information The records compiled here were obtained from correspondence within the Manitoba Rare Bird Alert, from rare bird files compiled by Rudolf F. Koes, and from my own field notes. Many of the records have been summarized in seasonal reports for the prairie provinces region in American Birds, and a few have been mentioned in other publications. ${ }^{1,5,10}$ Seasonal and geographic patterns of occurrence of Oldsquaws in southeastern Manitoba are summarized in Table 1, and records are mapped in Figure 1. An annotated list of all the records has been deposited with the Manitoba Ornithological Records Committee (MORC), c/o Manitoba Museum of Man and Nature, 190 Rupert Avenue, Winnipeg, Manitoba, R3B ON2. Relatively few of the records have been assessed by MORC, but most birds were seen by more than one experienced observer.

A Note on Identification Adult male Oldsquaws have strikingly different, but equally dramatic black-and-white nuptial and winter plumages. Adult females, eclipse males and immature birds are less distinctive, and are easily overlooked among more common diving ducks. Features to look for on these grayish-brown ducks include a rounded head and fairly short bill, and diffuse whitish facial markings that usually include a broad eye ring, supercilium and neckband. The dark breast-patch varies in intensity from blackish to 


\begin{tabular}{|c|c|c|c|c|}
\hline Table 1. & $\begin{array}{l}\text { MARY OF OBS } \\
\text { DUTHEASTERN }\end{array}$ & $\begin{array}{l}\text { ATIONS C } \\
\text { NITOBA, }\end{array}$ & $\begin{array}{l}\text { DSQUAWS } \\
\text { NGED BY }\end{array}$ & \\
\hline & $\begin{array}{c}\text { Sexton \& Collins } \\
\text { pre- } 1977\end{array}$ & $\begin{array}{l}\text { Additional } \\
\text { pre-1977 }\end{array}$ & $1977-1993$ & Total \\
\hline 11-20 April & 0 & $1(1)^{\star}$ & $1(1)$ & $2(2)$ \\
\hline 21-30 April & 0 & 0 & $1(1)$ & $1(1)$ \\
\hline 1-10 May & $2(2)$ & $1(1)$ & 0 & $3(3)$ \\
\hline 11-20 May & $1(1)$ & 0 & $5(7)$ & $6(8)$ \\
\hline 21-31 May & 0 & $1(1)$ & $1(2)$ & $2(3)$ \\
\hline Summer & 0 & 0 & $1(1)$ & $1(1)$ \\
\hline 11-20 September & $1(1)$ & 0 & 0 & $1(1)$ \\
\hline 21-30 September & $2(2)$ & 0 & 0 & $2(2)$ \\
\hline 1-10 October & 0 & 0 & $2(5)$ & $2(5)$ \\
\hline 11-20 October & $2(3)$ & 0 & $2(4)$ & $4(7)$ \\
\hline 21-31 October & $4(4)$ & 0 & $9(29)$ & $13(33)$ \\
\hline 1-10 November & 2(2) & 0 & $11(28)$ & $13(30)$ \\
\hline 11-20 November & 0 & 0 & $10(19)$ & $10(19)$ \\
\hline 21-30 November & 0 & 0 & $3(6)$ & $3(6)$ \\
\hline 1-10 December & 0 & 0 & $2(2)$ & $2(2)$ \\
\hline Winter & $2(2)$ & 0 & 0 & $2(2)$ \\
\hline${ }^{*}$ First figure is n & of records; fig & enthes & $r$ of indi & \\
\hline $\begin{array}{l}\text { Note - For repeat } \\
\text { interval was includ } \\
\text { observations, total } \\
\text { and } 10 \text { elsewhere. }\end{array}$ & $\begin{array}{l}\text { din the compilation } \\
8 \text { on or near the W }\end{array}$ & $\begin{array}{l}\text { location, the } \\
\text { cords from } 1 \\
\text { eg River; } 9\end{array}$ & $\begin{array}{l}\text { um number } \\
93 \text {, excludin } \\
\text { Winnipeg, }\end{array}$ & Manitoba, \\
\hline
\end{tabular}

barely off-white, and often has a diffuse outline. In flight, note the overall dark upper parts, with white outer tail-feathers, but no white wing markings; the flight also has an unusual "floppy" quality. When diving, Oldsquaws submerge effortlessly with the wings held partly open (a useful field characteristic shared with scoters and Harlequin Duck). They also tend to ride low in the water. A typical, nondescript immature Oldsquaw is shown in the accompanying sketch (Figure 2). Oldsquaws in southeastern Manitoba are usually noted alone, or as small groups loosely associated with concentrations of commoner diving ducks.

Spring Migration Sexton and Collins included three spring records (2, 7 and 11 May) in their compilation. Three additional pre-1977 spring re- ports have come to light in files at the Manitoba Museum of Man and $\mathrm{Na}-$ ture (R.F. Koes, pers. comm.). The Oldsquaw remains a rarity in this region in spring, with only six further records (eight birds) between 1977 and 1993 (Table 1). This is consistent with overall scarcity in the southern prairie provinces, as indicated by comments and records in various American Birds reports.

Janssen states that Oldsquaw migration from Minnesota waters of Lake Superior occurs in March and April, with only stragglers remaining in May. ${ }^{3}$ This contrasts with observations of spectacular flights - "one of the more awesome events of Manitoulin's ornithological calendar" involving thousands of birds near Manitoulin Island, Lake Huron, mainly between 16 and 23 May. ${ }^{6}$ 
Table 2. SUMMARY OF RECORDS

OF GROUPS OF THREE OR MORE OLDSQUAWS

\begin{tabular}{|l|l|l||}
\hline \multicolumn{1}{|c|}{ Date(s) } & \multicolumn{1}{c|}{ Location } & \multicolumn{1}{c|}{ Numbers and Observers } \\
\hline 8 October 1979 & Delta & 4: C.W. Cuthbert, G. Ogilvie \\
\hline 4 November 1979 & Winnipeg & 3: G.E. Holland \\
\hline 24 October 1981 & Red Rock Lake & 12-14: J.E. Christie \\
\hline 3 November 1984 & Grand Beach \& Grand Marais & 5: Man. Nat. Soc. field trip \\
\hline 24 November 1988 & Pinawa & 3: M. Siepman \\
\hline 22 October 1989 & Seven Sisters Falls & 4: P. Taylor \\
\hline 3-17 November 1990 & Pine Falls & $\begin{array}{l}\text { 5-6: P. Taylsr, m.ob. } \\
\text { 1 remained to 9 December }\end{array}$ \\
\hline 26 October-16 November 1991 & Pine Falls & $\begin{array}{l}\text { 3-7 (7 on 3 Nov.): R. Parsons, } \\
\text { m.ob. 1 remained on 17 Nov. }\end{array}$ \\
\hline
\end{tabular}

These likely contribute to the main arrival of Oldsquaws at Churchill in late May. ${ }^{4}$ The southeastern Manitoba spring records are scattered between 16 April and 24 May, with an ill-defined peak in mid-May (Table 1). This indicates that some, at least, are not associated with the major flight via the Great Lakes to Hudson Bay. Instead, they may arise from the wintering population on Lake Superior or scattered birds that have wintered elsewhere inland.

Summer Occurrence I observed a female Oldsquaw at close range at Natalie Lake, near Seven Sisters Falls, 4 July 1981. Any comment on the origin of this bird, so far from both the winter and summer ranges, would be entirely speculative.

Fall Migration The vast majority of recent Oldsquaw records in southeastern Manitoba have been in fall, mainly between late October and mid-November (Table 1). This peak is later than the migration of most other ducks. Of the other uncommon sea ducks in southeastern Manitoba, Surf Scoters peak in the first half of October, and Black and Whitewinged Scoters in the second half. ${ }^{12}$ Harlequin Ducks, like Oldsquaws, occur mainly between late October and mid-November. ${ }^{13}$ Of these five spe- cies, all except the White-winged Scoter occur much more frequently in fall than spring. The pattern of occurrence resembles that reported by Sexton and Collins, except that they included three September records and only two in November. ${ }^{8}$ The slight skewing of recent records towards later dates likely reflects the emphasis on field observation, as opposed to hunters' bag records. The late October peak coincides with arrivals on the Great Lakes and rare occurrence elsewhere in the southern prairie provinces and also along the Missouri River in South Dakota.,6,9

Recent Oldsquaw records include small groups of birds at several locations (Figure 1 and Table 2). Also interesting is the number of records at Pine Falls: singles on 17 November 1979, 24-25 November 1984 and 12 November 1989; up to six birds 3 November to 9 December 1990; up to seven, 26 October to 17 November 1991; two on 31 October and 6 November and one on 20 November 1993. Unlike Seven Sisters dam and vicinity, where multiple records have also occurred, the river at Pine Falls is only lightly used by other diving ducks (mainly Common Goldeneyes, Common Mergansers and Buffleheads). Thus, the Oldsquaw has been elevated from a rarity one might 


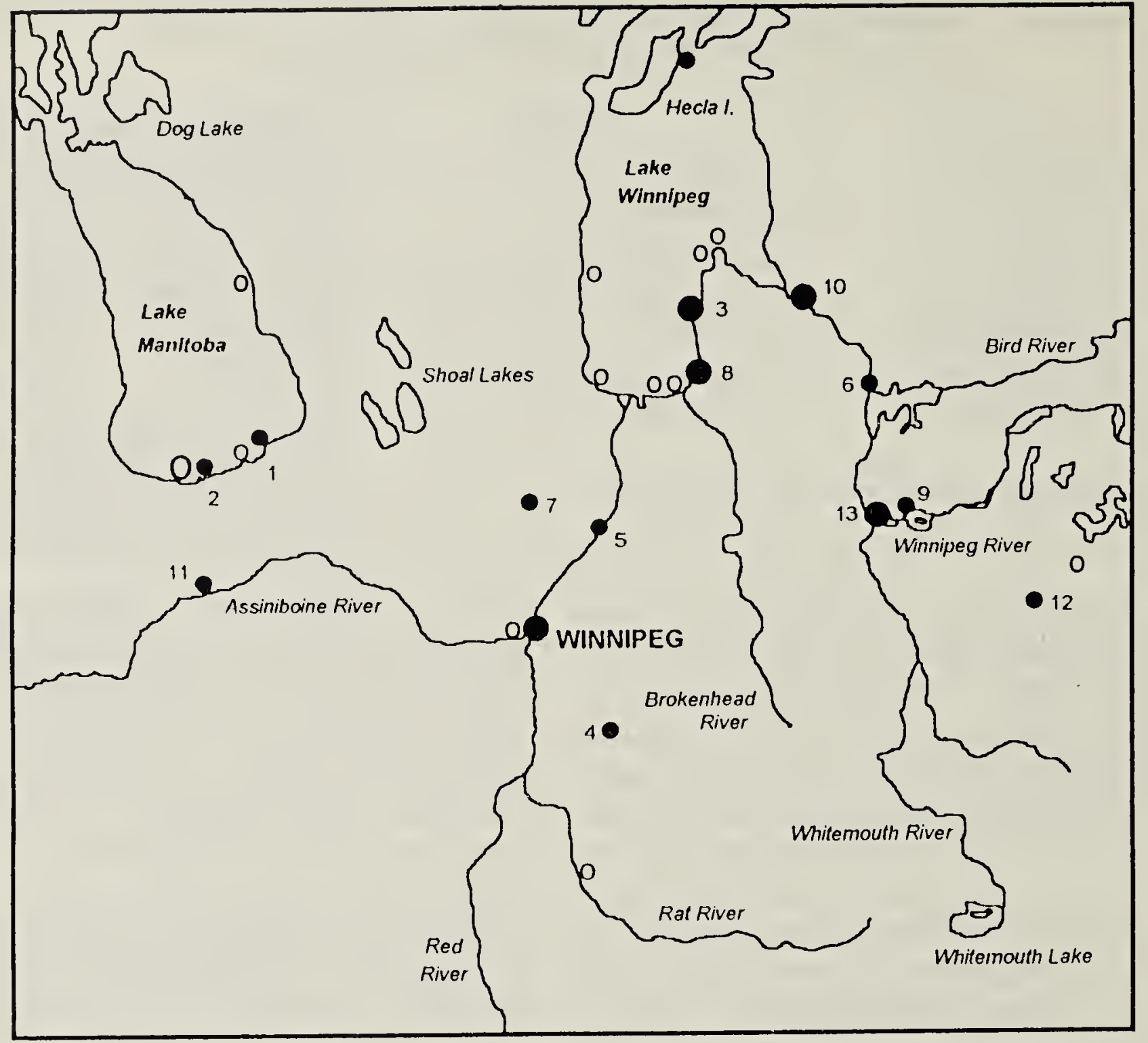

Figure 1. MAP OF SOUTHEASTERN MANITOBA, SHOWING LOCATIONS OF OLDSQUAW RECORDS. Large bullets indicate three or more records since 1976; small bullets indicate one or two records since 1976. Open circles indicate records prior to 1976, compiled by Sexton and Sollins ${ }^{\star * 8}$. Numbered localities are: 1 Clandeboye Bay and St. Ambroise; 2 Delta; 3 Grand Beach and Grand Marais; 4 Kleefeld; 5 Lockport; 6 McArthur Falls; 7 Oak Hammock Marsh; 8 Patricia Beach; 9 Pinawa; 10 Pine Falls and Powerview; 11 Portage la Prairie; 12 Red Rock Lake; 13 Seven Sisters Falls.

hope to see in southeastern Manitoba to a regular migrant that one might actually seek in small numbers at the appropriate place and season. The best time to look is shortly after a strong, cold northerly wind in late October or early November.

Winter Lingerers Two recent, early December records on the Winnipeg River (Pine Falls, 9 December 1990; Seven Sisters Falls, 4 December 1993) appear to represent straggling migrants, rather than overwintering attempts. Sexton and Collins noted two winter records - one bird frozen at Elk Island in 1934, and a second that became a most unusual roadkill near St. Malo in February $1972 .^{8}$ The Oldsquaw is a common winter visitor on Lake Superior near Cook County, Minnesota, just $400 \mathrm{~km}$ from the Manitoba border. ${ }^{3}$ Thus, occasional winter occurrence on the limited open water in southern Manitoba might reasonably be expected. However, Common Goldeneyes are the only ducks that overwinter on the Winnipeg River in significant numbers. ${ }^{10}$

I thank Rudolf $F$. Koes for information and helpful comments on a draft manuscript. 


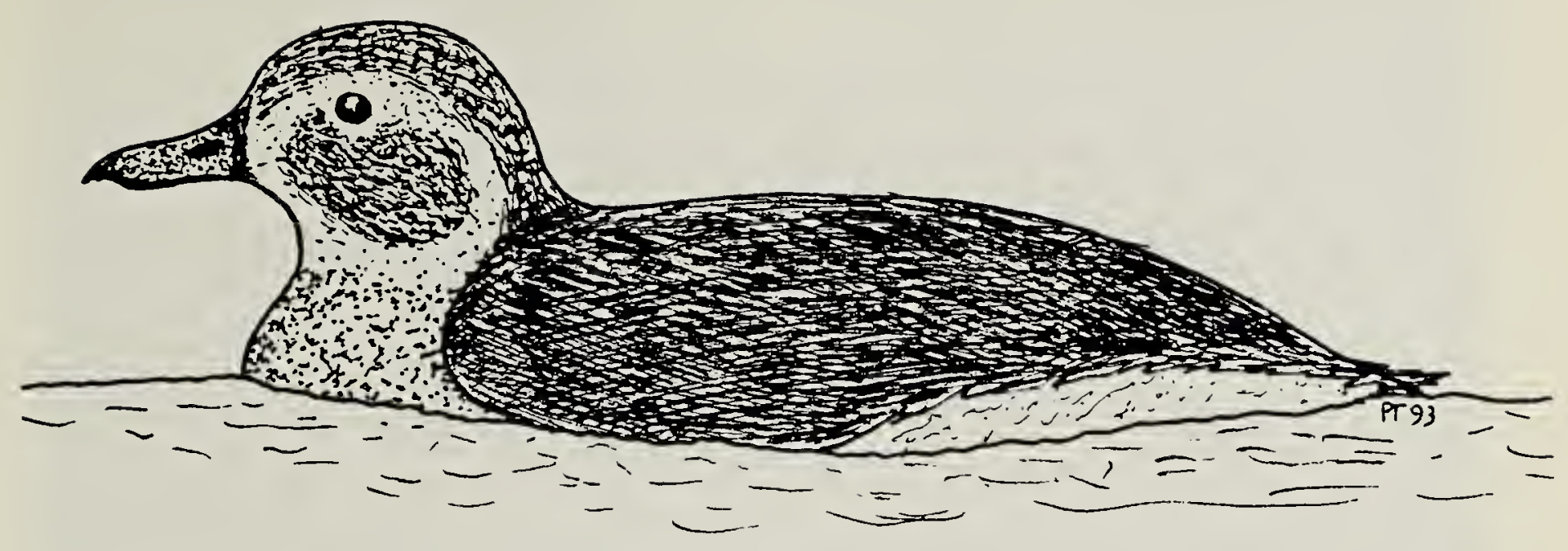

Figure 2. Immature Oldsquaw in full plumage.

Peter Taylor

1. GARDNER, K.A. 1981. Birds of Oak Hammock Marsh Wildlife Management Area. Available from Manitoba Museum of Man and Nature, Winnipeg. $172 \mathrm{pp}$.

2. GODFREY, W.E. 1986. The birds of Canada, revised edition. Natl. Mus. Can., Ottawa. 595 pp.

3. JANSSEN, R.B. 1987. Birds in Minnesota. University of Minnesota Press, Minneapolis. 352 pp.

4. JEHL, J.R., Jr. and B.A. SMITH. 1970. Birds of the Churchill Region, Manitoba. Special Publ. No. 1, Manitoba Mus. of Man and Nature, Winnipeg. 87 pp.

5. KNAPTON, R.W., R.F. KOES and P. TAYLOR. 1978. Rare waterfowl in southern Manitoba, 1977. Blue Jay 36:214-215.

6. NICHOLSON, J.C. 1981. The birds of Manitoulin Island and adjacent islands within Manitoulin District. Published privately, Sudbury, Ont. 204 pp.

7. SALT, W.R. and J.R. SALT. 1976. The birds of Alberta, with their ranges in Saskatchewan and Manitoba.

Hurtig, Edmonton. 498 pp.

8. SEXTON, D.A. and K.M. COLLINS. 1977. Records of the Oldsquaw in southern Manitoba. Blue Jay 35:9699.

9. SOUTH DAKOTA ORNITHOLOGISTS UNION. 1991. The birds of South Dakota. Revised edition. Aberdeen, SD. 411 pp.

10. TAYLOR, P. 1983. Wings along the Winnipeg: the birds of the Pinawa Lac du Bonnet region, Manitoba. Eco Series No. 2, Manitoba Naturalists Society, Winnipeg. 216 pp.

11. - 1993. Mid-continental jaegers: a Manitoba perspective. Blue Jay 51:157-164.

12. TAYLOR, P. and R.F. KOES. 1987. Scoter migration in southeastern Manitoba, 1975-1986. Blue Jay 45:166-171.

13. TAYLOR, P. and J.E. THOMPSON. 1990. Harlequin Duck in Manitoba: an update. Blue Jay 48:98-103. 